\title{
Econometric Analysis of Factors Affecting Haricot Bean Market Outlet Choices in Misrak Badawacho District, Ethiopia
}

\author{
Shewaye Abera \\ Etiopian Institute of Agricultural Research \\ Fogera National Rice Research and Training Center \\ P.O.Box 1937, Bahir Dar, Ethiopia
}

\begin{abstract}
This study was undertaken with the objective of identifying factors affecting haricot bean market outlet choices in Misrak Badawacho District, Ethiopia. Multivariate Probit model (MVP) were used to analyze the determinant factors that affect the choices of market outlet of smallholder haricot bean farmers. In the study area rural assemblers, direct consumers and urban traders marketing outlets were used by haricot bean producer farmers. MVP model result revealed that distance to all weather road and distance to the nearest district market had a positive association for the probability to choose the rural assemblers market outlet whereas, number of equine owned and use of credit had a negative association. The probability to choose direct consumers outlet number of equine owned had a positive association. Number of equine owned, use of credit, membership in cooperative and price information had positive association, where as distance to the nearest district market were negatively affected the probability to choose the urban traders outlet. Therefore, this implies that the need to invest on improving the present infrastructure like roads and transportation facilities, market information delivery system; strengthening the rural microfinance system to address the credit needs of farmers and promoting farmers group are vital area of intervention that would assist smallholder farmers to choose the more rewarding market outlet.
\end{abstract}

Keywords: Market outlet choices, Smallholder haricot bean farmers, Multivariate probit model.

\section{INTRODUCTION}

Ethiopian agriculture is dominated by subsistence oriented, natural resource intensive, low input low output; rain-fed farming system [1]. The development of Ethiopian economy heavily depends upon the pace with which the agricultural growth achieved. The rate of agricultural growth also depends upon the pace with which the current subsistence oriented production system is transformed into market oriented production system [2]. In development policy planning, transformation of smallholder agriculture to market oriented production system is agreed to be a solution for the existing problems of poverty and food security in the rural Ethiopia [3].

Markets provide households the opportunity of welfare gains from trade through specialization according to comparative advantage [4]. Market participation has seen as a solution to increase the welfare of smallholders in developing countries and move them out from the poverty trap [5]. Integration of smallholders into markets is essential for sustainable development of the agricultural sector in agriculture-based economies [6]. Smallholder market participation depends on various factors including farm productivity, access to input supply and services, access to output markets.[7], transaction costs [8] and [9].

Choice of market outlets is a very important part in market participation decision. Farm households make a number of decisions in their daily activities. Marketing outlet choice is one of the most important farm household decisions to sell their produce in different marketing outlets and has a great impact on household income [10] and [11]. Market outlets choices are household specific decision and several drivers have to be considered as a basis for such decision. Various empirical studies pointed out that smallholder farmers decision to choose different market outlet can be affected by household characteristics, resource endowments and access to different market outlets [10]; prices and transportation cost.[12] and [13] and according to [11] lack of market knowledge or difficulties in accessing markets that are more rewarding makes smallholder farmers to transact their produce through outlet offering low price. 
Thus, factors affecting market outlet choices of smallholder haricot bean farmers result become essential to provide imperative information for effective research planning and intervention. Therefore this study attempts to investigate how the characteristics of smallholder farmers, their resource endowment, transaction costs, institutional arrangements and service delivery jointly affects haricot bean market outlet choices.

\section{Methodology}

\subsection{Study Area and Sampling Techniques and Sample Size}

The study was conducted in Misrake Badawach district of Hadiya zone of Southern Nations Nationalities and Peoples Regional State (SNNPRS), Ethiopia. Cross sectional data were collected from 123 randomly selected haricot bean producer households in 2014 production season. A two stage random sampling technique was used to select sample respondents. In the first stage six kebeles were selected randomly. From the selected kebeles, haricot bean producer farm households were identified in collaboration with development agents. In the second stage a total of 123 haricot bean producer farm households were selected randomly from the selected sample kebeles by using simple random sampling technique. The sample size in each kebele was determined proportional to Size of the identified haricot bean producer households. Out of the total 123 sample households only 84 households that participated in market were included in this analysis.

\subsection{Method of Data Analysis}

Both descriptive statistics and econometric analysis were used to meet the specific objective of this study. In descriptive statistics mean, standard deviations, frequency and percentage were used to describe the hypothesized variables. Whilst for econometric analysis MVP model were used.

The econometric model were used to identify the household characteristics, resource endowment, transaction costs, institutional arrangements and service delivery factors that were hypothesized as determinants of haricot bean producers farmers market outlet choices. However, in market outlet choice one actor may involved in one or more than one type of market outlets due to these, MVP was preferred because it simultaneously capture the influence of the set of explanatory variables on each of the different outlets choices, while allowing the unobserved (error terms) to be freely correlated.

MVP model was used to analyze the determinants of farmers' decisions on market outlet choices; because farmers more likely choose a different outlet simultaneously. The household decision of whether or not to choose is considered under the general frame work of utility or profit maximization. In this context, the utility of the economic agents is not observable, but the actions of the economic agents could be observed through the choices they made. Following [14] the functional form of multivariate probit model is specified as follows, econometric approach for this study is characterized by a set of binary dependent variables $y_{i t}$ such that

$$
\begin{aligned}
y_{i t}^{*} & =x_{i t}^{\prime} \beta+\varepsilon_{i t}, \quad \mathbf{i}=\mathbf{1}, \ldots, \mathbf{n} \quad \mathbf{t}=\mathbf{1}, \ldots, \mathbf{T} \\
y_{i t} & =\left\{\begin{array}{l}
1 \text { if } y_{i t}^{*}>0, \\
0, \text { otherwise }
\end{array}\right.
\end{aligned}
$$

Where $\mathrm{t}=1,2, \ldots \mathrm{T}$ denotes the market outlet choices available;

$x_{i t}^{\prime}$ is a vector of explanatory variables,

B denotes the vector of parameters to be estimated, and

$\varepsilon_{i t}$, are random error terms distributed as multivariate normal distribution with zero means and variance-covariance matrix $\mathrm{V}$.

Where $\mathrm{V}$ has values of 1 on the leading diagonal and correlations $\mathrm{tT}=\mathrm{Tt}$ as off-diagonal elements. It is assumed that a rational $i^{\text {th }}$ farmer has a latent variable, $\mathrm{y}^{*}$ it which captures the unobserved preferences or demand association with the $\mathrm{t}^{\text {th }}$ choice of market outlet choice. This latent variable is assumed to be a linear combination of observed households and other characteristics that affect the market outlet choice, as well as unobserved characteristics captured by the stochastic error term.

Given the latent nature of the variable, $\mathrm{y}^{*}$ it, the estimation is based on the observed variable $\mathrm{y}_{\mathrm{it}}$ which indicates whether or not a household choose a particular market outlet. Since choosing of several market outlet choices is possible, the error terms in equation (1) are assumed to jointly follow a multivariate normal distribution, with zero conditional mean and variance normalized to unity. The off-diagonal elements in the covariance matrix represent the unobservable correlation between the 
stochastic components of the type of choice outlets. This assumption means that Equation (2) gives a MVP model that jointly represents decisions to choose a particular market outlet. This specification with non-zero off-diagonal elements allows for correlation across the error terms of several latent equations which represent unobserved characteristics that affect the choice of alternative outlets choices.

\subsection{Hypothesized Variables}

In the case of identifying factors influencing haricot bean market outlet choice decisions, the main task were exploring which factors potentially influence and how these factors are related with the dependent variables. Therefore, the following dependent and independent variables were hypothesized in the study.

\subsection{Dependent Variable}

Haricot bean Market outlet choice (HMOC): The outlet choice is farmers' decision involving different alternative market outlets. It is measured by the probability of farmers 'selling haricot bean to either of marketing outlets.

Table 1 indicates the summary of hypothesized independent variables which was used in the econometric analysis .

Table 1. Summary of hypothesized independent variables.

\begin{tabular}{|l|l|l|}
\hline Variable & Variable definition & \multicolumn{1}{c|}{ Value } \\
\hline SEX & Sex of the Household Head & $0=$ male, $1=$ female \\
\hline AGE & Age of the household head & Years \\
\hline EDUCATION & Education of the Household Head & $0=$ illiterate, $1=$ literate \\
\hline NEQUINE & Number of equine owned & Number \\
\hline MCOOP & Membership in cooperative & $1=$ member, $0=$ otherwise \\
\hline UCREDIT & Use of credit & $1=$ used, $0=$ No \\
\hline DISTNM & Distance to the nearest market & Kilometer \\
\hline DISTAWR & Distance to all weather road & kilometer \\
\hline API & Access to price information & $1=$ access, $0=$ otherwise \\
\hline
\end{tabular}

\section{RESUlT AND DISCUSSION}

Descriptive statistics result, the mean and standard deviation of continuous variables by haricot bean market outlets are provided in Table 2. The mean age of household heads that had access to rural assemblers, direct consumers and urban traders' market outlets were about 42 years. Households that sell to urban traders on average owned 2.28 equines than those who supplied to rural assemblers (equine1.07) \& direct consumers (equine1.22). This implies that households who supplied to urban traders have access to more equine to transport their produce to farther markets. Distance travelled to the nearest district market and all weather roads were the highest for households who had access to rural assemblers i.e. $9.78 \mathrm{~km}$ and $7.71 \mathrm{~km}$, respectively and were the lowest for households who had access to urban traders and direct consumer i.e. on average about $5 \mathrm{~km}$ and $3 \mathrm{~km}$, respectively.

Table 2. Mean and standard deviation of continuous variables that affects market outlets choice

\begin{tabular}{|c|c|c|c|c|c|c|}
\hline \multirow{2}{*}{ Explanatory Variables } & \multicolumn{6}{|c|}{ Mean and standard deviation of market outlets } \\
\cline { 2 - 7 } & \multicolumn{2}{|c|}{$\begin{array}{c}\text { Rural assemblers } \\
\mathrm{N}=43\end{array}$} & \multicolumn{2}{c|}{$\begin{array}{c}\text { Direct consumers } \\
\text { N=48 }\end{array}$} & \multicolumn{2}{c|}{$\begin{array}{c}\text { Urban traders } \\
\text { N=58 }\end{array}$} \\
\cline { 2 - 7 } & mean & Std.dev. & mean & Std.dev. & mean & Std.dev. \\
\hline Age & 41.67 & 7.64 & 41.71 & 8.57 & 41.94 & 8.74 \\
\hline $\begin{array}{c}\text { Ownership of } \\
\text { transport equine }\end{array}$ & 1.07 & 0.93 & 1.22 & 1.11 & 2.28 & 1.15 \\
\hline $\begin{array}{c}\text { Dist. to the nearest } \\
\text { district market }\end{array}$ & 9.78 & 6.66 & 5.38 & 5.38 & 5.07 & 5.36 \\
\hline $\begin{array}{c}\text { Distance to all } \\
\text { weather road }\end{array}$ & 7.71 & 2.68 & 3.08 & 2.61 & 3.16 & 2.45 \\
\hline
\end{tabular}

Source: own survey data, 2014

In the study area three market outlets were used by haricot bean producing farmers. Out of these, large numbers of haricot bean producer farmers were chosen urban traders, followed by direct consumers and rural assemblers outlets. Moreover, the proportion of haricot bean supplied by sample households 
to rural assemblers, direct consumers and urban traders marketing outlets were $26 \%, 14 \%$ and $60 \%$, respectively. On average terms the volume of haricot bean supplied to rural assemblers, direct consumers and urban traders were $354 \mathrm{~kg}, 473 \mathrm{~kg}$ and $507 \mathrm{~kg}$, respectively (Table 3 ).

Table 3. Producer market outlet, choices and volume of haricot bean supply to each outlets

\begin{tabular}{|c|c|c|c|c|c|}
\hline \multirow{2}{*}{ Market outlets } & Producers choice & \multicolumn{4}{|c|}{ Volume supplied in kg } \\
\cline { 2 - 6 } & Frequency & Mean & Std. & Total & $\%$ age \\
\hline Rural assemblers & 43 & 354 & 2.18 & 19,825 & 26 \\
\hline Direct consumers & 48 & 473 & 3.75 & 10,400 & 14 \\
\hline Urban traders & 58 & 507 & 2.93 & 45,160 & 60 \\
\hline Total & & & & 75,385 & 100 \\
\hline
\end{tabular}

\section{Source: own survey data, 2014}

\section{Factors affecting smallholder haricot bean producers market outlet choices}

The model results in Table 4 reveals the choice set in the MVP model includes three outlet choices; which were rural assemblers', urban traders', and direct consumers outlet. The samples were drawn 100 times. The matrix rho, rho were represented the correlation coefficient matrix between rural assemblers, and direct consumers, rural assemblers and urban traders and direct consumers and urban traders, respectively. The likelihood ratio test result indicated that, the correlation coefficients are statistically different from zero in one of the three cases, verifying the goodness of fit of the multivariate probit model and outlet choices are mutually interdependent. The Wald $\chi^{2}$ test value of 79.25 which is significant at $1 \%$ significance level reveals separate estimation of choice of these outlets is biased and the decisions to choose the three outlets were interdependent.

Table 4. Factors affecting market outlet choices of smallholder haricot bean producers

\begin{tabular}{|c|c|c|c|c|c|c|}
\hline \multirow[t]{2}{*}{ Explanatory variables } & \multicolumn{2}{|c|}{ Rural assemblers } & \multicolumn{2}{|c|}{ Direct consumers } & \multicolumn{2}{|c|}{ Urban traders } \\
\hline & Coef. & $\begin{array}{c}\text { Robust } \\
\text { std. }\end{array}$ & Coef. & $\begin{array}{l}\text { Robust } \\
\text { std. }\end{array}$ & Coef. & $\begin{array}{l}\text { Robust } \\
\text { std. }\end{array}$ \\
\hline Age & 0.011 & 0.019 & 0.005 & 0.019 & 0.006 & 0.020 \\
\hline Sex & -0.313 & 0.394 & 0.673 & 0.461 & 0.259 & 0.413 \\
\hline Education & 0.052 & 0.331 & 0.170 & 0.388 & 0.412 & 0.386 \\
\hline Number of equine owned & -0.371 & $0.167 * *$ & 0.416 & $0.183 * *$ & 0.426 & $0.167 * *$ \\
\hline Access to price information & -0.341 & 0.372 & -0.240 & 0.421 & 1.017 & $0.386 * * *$ \\
\hline Membership in Cooperatives & -0.467 & 0.413 & -0.264 & 0.462 & 1.039 & $0.397 * * *$ \\
\hline Use of Credit & -0.615 & $-0.359 *$ & 0.390 & 0.369 & 0.937 & $0.373 * *$ \\
\hline Dist. to the nearest district market & 0.104 & $0.034 * * *$ & -0.044 & 0.030 & -0.068 & $0.025 * * *$ \\
\hline Distance to all weather road & 0.153 & $0.061 * *$ & -0.001 & 0.056 & -0.008 & 0.067 \\
\hline Constant & -0.367 & 0.043 & 0.599 & 1.327 & -3.036 & 1.193 \\
\hline Rho21 & $-0.835 * * *$ & & & & & \\
\hline Rho31 & $-0.385^{* *}$ & & & & & \\
\hline Rho32 & 0.277 & & & & & \\
\hline Predicted probability & 0.506 & & 0.572 & & 0.686 & \\
\hline Joint probability(success) & 0.150 & & & & & \\
\hline Joint probability(failure) & 0.039 & & & & & \\
\hline $\mathrm{N}$ & 84 & & & & & \\
\hline Number of simulation(draws) & 100 & & & & & \\
\hline Log pseudo likelihood & -119.81 & & & & & \\
\hline Wald chi2(30) & $79.25 * * *$ & & & & & \\
\hline $\begin{array}{l}\text { Likelihood ratio test of rho21- } \\
\text { rho31=rho32=0: } \operatorname{chi} 2(3)\end{array}$ & 21.629 & & & & & \\
\hline Prob $>$ chi $2=0.0001$ & & & & & & \\
\hline
\end{tabular}

Dependent variable is market outlet choices, $* * *, * *$ and * are statistically significant at $1 \%, 5 \%$ and $10 \%$, respectively.

Source: own survey data, 2014.

The Simulated Maximum Likelihood(SML) estimation results suggested that $\rho$-values (degree of correlation between each pair of the dependant variable) statistically significant levels. These were a negative and significant interdependence between household decisions to choose rural assemblers outlet choice with direct consumers' at $1 \%$ significance level, and rural assemblers with urban traders' outlet choice were also negatively and significantly interdependent at 5\% Significance level, 
but not between direct consumers outlet and urban traders. This indicates the choice of rural assemblers' outlet was significantly decrease the choice of direct consumers' and urban traders' outlets, as the households' decision to choose one type of outlet reduces choice of the other outlets.

Some of the explanatory variables were significant to affect the decision made by farmers about a particular market outlet choice and it can be insignificant for the other outlets choices. Thus, the multivariate probit analysis result reveals the decision of each market outlet choices was influenced by the same or different factors at different or same level of significance.

Number of equine owned: the regression coefficient of number of equine owned was found to have a positive and significant influence on the probability of haricot bean producer farmers decision to choose direct consumers and urban traders outlets and negative and significant influence on rural assemblers' outlet. Equine ownership plays vital role in lowering transportation costs as well as farmers who have equine transport go distant market and choose more than one market to sell their produce and so be able to achieve higher price. This agrees with the findings of [15] that transport ownership allow farmers to sell their produce to marketing center located far off. The result reveals having equine increases the probability of choosing the farther and achieving the higher price market outlets.

Membership in cooperative: It had significant influence on market outlet choices. Household membership in cooperative could have better access to information that helps to production and marketing decisions. Membership in cooperative can also contribute towards reduced transaction costs and strengthen farmers bargaining power through networking and provision of up to date information to members. Therefore, the result reveals being a member in cooperatives increases the likelihood of choosing urban traders outlet. This agree with the findings of [16],[17]and [18].

Use of credit: Farmers who use credit may produce more output this might be due to use of credit provide for farm households a power to spend in input market that boost yield and thus leading to more marketable surplus. Likewise, use of credit eases liquidity constraints of households that contribute to market oriented production. Therefore, the result reveals using credit reduces the probability of choosing rural assemblers market outlet and increases the probability of choosing urban traders. This confirms the finding of [11].

Distance to the nearest district market: was an important variable that affect significantly the probability of haricot bean producer farmers decision to choose market outlets to sell their produce. The negative coefficient for urban trader outlet and positive sign for rural assemblers outlet reveals farmers who are located farther away from market face higher transaction costs and so may opt for rural assemblers in their villages or in nearby villages rather than selling to urban traders in more distant market that increase transaction costs. This confirm the findings of [16] and [17].

Distance to all weather roads: was found to have a significant and positive effect in the decision of choosing rural assemblers outlet. The assumption here is that the closer a household farm or house to all weather road, the more will be the transportation facilities access. Proximity of farmers to all weather roads is essential for output disposal. This implies that farm households located far from allweather road facing high transportation costs and thereby leading to decide to choose the nearby market outlet i.e. the rural assembler's market outlet. This result confirms the finding of [19] that distance to the tarmac road impedes the choice of private traders.

Price information: was an important variable that affect significantly the probability of haricot bean producer farmer's decision to choose market outlets to sell their produce. The positive coefficient for urban trader outlet reveals having price information of different market outlets can create an opportunity to opt the best rewarding outlets. This agree with the findings [18] and [10] that price information can reduce transaction costs and improves the bargaining power of smallholder farmers.

The marginal success probability for each equation or market outlet choice decision result reveals the likelihood of choosing rural assemblers outlet was relatively low (51\%) as compared to the probability of direct consumers outlet (57\%) and urban traders (69\%). This was due to the fact that rural assemblers outlet offered lower price as compare to other outlets. Hence, haricot bean producer constraint to choose rural assemblers outlet. 
The joint probabilities of success or failure of choosing the three market outlets suggest that households were more likely to succeed to jointly choose the three market outlets. The likelihood of households' success to jointly choose the three market outlets were $15 \%$ compared to their failure to jointly choose the three market outlets of them were $3.9 \%$.

\section{CONCLUSION AND IMPLICATIONS}

Factors affecting haricot bean market outlets choice were analyzed by Multivariate probit model. The result indicated that the outlet choice of rural assemblers was negatively and significantly influenced by number of equine owned and use of credit and positively influenced by distance to the nearest district market and distance to all weather road with $51 \%$ predicted probability of marginal success. Whereas direct consumers outlet was positively and significantly affected by number of equine owned with 57\% predicted probability of marginal success. Urban traders market outlet was positively and significantly affected by number of equine owned, membership in cooperative, access to price information and use of credit and also negatively and significantly affected by distance to the nearest district market with $69 \%$ predicted probability of marginal success.

Based on the findings of this study, some relevant implications can be drawn that can assist to design appropriate intervention mechanisms to improve market outlets choice of haricot bean farmers in the study area. Interventions intended at reducing transaction costs through rural infrastructure investment in the form of establishing all weather road, improving market information delivery system in order to avoid information asymmetry, improving smallholder farmers access to credit though strengthening rural micro finance and encouraging membership in cooperatives are vital area of intervention that would assist farmers to choose the more rewarding market outlets

\section{REFERENCES}

[1] Ministry of Agriculture and Rural Development, Ethiopia's agricultural and Sector Policy and Investment Framework (PIF): 2010-2020, Addis Ababa (2010).

[2] Berhanu Gebremedhin, D.Hoekstra and Azage Tegegne, Commercialization of Ethiopian agriculture: Extension service from input supplier to knowledge broker and facilitator,2006. Working Paper 1. ,Addis Ababa,Ethiopia.

[3] Habtamu Yesigat, Impact of Input and Output Market Development Interventions: A case of Improving Productivity and Market Suceess (IPMS) Project in Bure District, International Journal of Sustainable Economies Management, 1(1): 39-51 (2012).

[4] Barrett C.B., Smallholder market participation: concepts and evidence from eastern and southern Africa. Food Policy, pp. 299-317 (2008).

[5] World Bank, World Development Indicators. Green Press Initiative, World Bank, Washington, DC (2007).

[6] World Bank, World Development Report 2008: Agriculture for development. Washington, DC (2008).

[7] Berhanu Gebremedhin, Moti Jaleta, and D.Hoekstra, Smallholders, Institutional Services and Commercial Transformation in Ethiopia, Agricultural Economics.40(5): 737-787 (2009).

[8] Key, N., E. Sadoulet, and A. de Janvry, Transaction Costs and Agricultural Household Supply Response, American Journal of Agricultural Economics, 82(2):245-259 (2000).

[9] Alene AD, V.M. Manyong, G.Omanya, H.D. Mignouna, M. Bokanga and G.Odhiambo, Smallholder market participation under transactions costs: Maize supply and fertilizer demand in Kenya, Food Policy. 33(4)-328 (2008).

[10] Moti Jaleta, Econometric analyses of horticultural production and marketing in Central and Eastern Ethiopia. PhD Thesis Wageningen University.Netherland (2007)

[11] Mmbando, F.E., E.Z. Wale, L.J .S. Baiyegunhi, and M.A.G. Darroch, The choice of marketing channel by maize and pigeonpea smallholder farmers: Evidence from Northern and Eastern zones of Tanzania. PhD dissertation University of KwaZulu- Natal Pietermaritzburg. South Africa. Pp.62-78 (2014)

[12] Fafchamps, M. and R.V. Hill, Selling at the farm-gate or traveling to market. American Journal of Agricultural Economics, 87(3):717-734 (2005). 
[13] Van Schalkwyk, H. D., Groenewald, J. A., Fraser, G. C. G., Obi, A., \& van Tilburg, A,Unlocking markets for smallholders: Lessons from South Africa (Vol. 10). Wageningen, the Netherlands: Wageningen Academic Publishers (2012).

[14] Greene, W. H., Econometric Analysis, Fifth edition. Pearson Education International, USA (2003).

[15] Panda, P.K., and Sreekumar, Marketing channel choice and marketing efficiency assessment in agribusiness, Journal of International Food and Agribusiness Marketing24(3):213-230 (2012).

[16] Berhanu Kuma, Derek Baker, Kindie Getnet and Belay Kassa, African Journal of agricultural Marketing, 1(2), 024-031 (2013).

[17] Xaba B. G. and M. B. Masuku, Factors Affecting the Choice of Marketing Channel by Vegetable Farmers in Swaziland, Sustainable Agriculture Research, 2(1) (2013).

[18] Siege G., H. Bett. and L. kibet, Determinants of Market Participation among Small-scale Pineapple Farmers in Kericho County, Kenya. MPRA Paper No.56149 (2014).

[19] Chirwa, E.W., Determinants of marketing channels among smallholder maize farmers in Malawi. Department of Economics, University of Malawi. Working Paper No.2009/03 (2009). 